\title{
Induced Mutagenesis for Morphological Changes in Gladiolus (Gladiolus grandiflorus L.)
}

\author{
Abhilash Shukla ${ }^{1}$, Gaurav Sharma ${ }^{2}$, Sushil Kashyap ${ }^{3}$ and Manisha Netam ${ }^{4}$ \\ ${ }^{1}$ Department of Horticulture, ${ }^{4}$ Department of Agriculture and Biotechnology, \\ Government of Chhattisgarh, Deputy Director Horticulture office, \\ Jagdalpur, Dist Bastar, 494001, India \\ ${ }^{2}$ Department of Floriculture and Landscape Architecture, Indira Gandhi Krishi \\ Vishwavidayalaya, Raipur, 492012, India \\ ${ }^{3}$ Indira Gandhi Krishi Vishwavidyalaya, KVK Jagdalpur, Dist Bastar, 494001, India \\ *Corresponding author
}

\begin{tabular}{|c|c|}
\hline & A B S T R A C T \\
\hline $\begin{array}{l}\text { Gamma, Grays, } \\
\text { Gladiolus, } \\
\text { Morphology }\end{array}$ & \multirow{3}{*}{$\begin{array}{l}\text { The present investigation was carried out on gladiolus with three cultivars which was } \\
\text { irradiated with 15, 30, 45, and } 60 \text { Gy of gamma radiation at Department of Nuclear } \\
\text { Agriculture and Biotechnology Division (NABTD), BARC, Trombey, Mumbai during } \\
\text { November } 2016 \text { and field evaluation was carried out at Instruction Farm Department of } \\
\text { Floriculture and landscape architecture, IGKV, Raipur. The experiment was laid out in } \\
\text { Factorial Randomized Block Design with fifteen treatments replicated three times. Results } \\
\text { indicated that the mutagenic treatments at lower doses had significant stimulative effect on } \\
\text { some parameters i.e., sprouting percentage, days taken to sprouting, spike initiation, } \\
\text { opening of first florets whereas most of the morphological parameters showed a decrease } \\
\text { from desired levels i.e., survival rate, plant height and number of leaves. Higher doses } \\
\text { gamma rays were detrimental for vegetative characters. }\end{array}$} \\
\hline Article Info & \\
\hline $\begin{array}{l}\text { Accepted: } \\
\text { 18 October } 2018 \\
\text { Available Online: } \\
\text { 10 November } 2018\end{array}$ & \\
\hline
\end{tabular}

\section{Introduction}

Gladiolus (Gladiolus grandiflorus L.) is an important ornamental and commercial flower, belongs to the family Iridaceae. Gladiolus is a flower of glamour and perfection which is known as the queen of bulbous flowers due to its flower spikes with florets of massive form and excellent self life. It is a popular flowering plant and is a native of South Africa and Asia Minor. In India gladiolus has become the most popular commercial cut flower crop and the demand for multicolored varieties are increasing day by day. There are about 260 species in genus Gladiolus (Singh et al., 2006). The presently cultivated gladiolus hybrids ( $G$. grandiflorus L.) have been developed genetically from 20-25 species out of many species found in its native.

Apart from its production as cut flower, it is also very much in demand for bouquets and 
landscaping. With the income in demand for gladiolus flowers, the demand for novel flower color and type is also on rise. The demand of gladiolus is increasing therefore it needs attention towards genetic improvement. Mutation breeding has become a routine technique in many vegetatively propagated ornamental plants. Flower color chimeras can arise by mutagenic treatment and depend on the type of material used and the regeneration process. In contrast to other traits, flower color mutants can readily be recognized even if very small sectors are affected. Gladiolus is highly heterozygous in its genetics constitution which makes it promising test material for inducing physical mutagenesis.

The main advantage of mutation induction is that the changes can be retained through vegetative propagation. Gladioli are vegetatively propagated by corms and cormels most suited for commercial exploitation through mutation breeding without any homozygosity and loss of any desirable characters. Many mutants for different attractive colours have earlier been isolated. Ornamental plants are ideal for the application of mutation induction techniques because many characters of economic interest, i.e., flower traits (novelty, doubleness, petaloides, dwarfness, vase life), are easily monitored after the mutagenic treatment. The present study was aimed to ascertain the radiosensitivity of three gladiolus varieties as well as to induce mutations.

\section{Materials and Methods}

The present study was conducted at the Horticulture Research cum Instructional Farm, Department of Floriculture and Landscape Architecture, Indira Gandhi Krishi Vishwavidyalay, Raipur (C.G.) during the year 2016-17. The site is located between $21^{\circ} 14^{\prime} 06.8^{\prime \prime} \mathrm{N}$ latitude and $81^{\circ} 42^{\prime} 41^{\prime \prime} \mathrm{E}$ longitude at an altitude of $289.56 \mathrm{~m}$ above mean sea level. Radiation treatment of dormant corms (3.5 to $4.5 \mathrm{~cm}$ diameter) of three varieties of gladiolus viz., Candyman, American Beauty and Her Majesty was done at Department of Nuclear Agriculture and Biotechnology Division (NABTD), BARC, Trombey, during November 2016. The crop was raised under standard uniform cultural conditions planted in November 2016 and harvested in April 2017. The experiment was laid out in Factorial Randomized Block Design as suggested by Panse and Sukhatme (1967). Treatments were undertaken by using of four level gamma doses i.e., $15 \mathrm{~Gy}, 30 \mathrm{~Gy}$, $45 \mathrm{~Gy}, 60 \mathrm{~Gy}$, and control (untreated) on three varieties of gladiolus. Per treatment sixteen corms were planted and each treatment was replicated thrice. The data were recorded on growth and morphological parameters and statistically analyzed using OPSTAT software.

\section{Results and Discussion}

\section{Days taken to sprout}

In respect of cultivars data presented in Table 1 revealed that minimum days (6.73 days) to sprouting of corms were recorded in Ameican Beauty while, maximum days to sprouting were recorded in cv. Candyman (7.67 days), followed by cv. Her Majesty (7.80 days). The gamma radiation treatments effect on days taken for sprouting was found to be non significant. Similar results were observed by Srivastava et al., (2007), Patil and Dhaduk (2009) in gladiolus and Singh et al., (2009) in marigold, who reported that higher radiation doses having adverse effect on days required for sprouting. Low level of mutagen itself is not responsible for early sprouting of gladiolus but it influence the activity of enzymes (Singh and Kumar, 2013). Mutagens influence the activity of enzymes, enzymes play a pivotal role in various plant metabolism activities consequently result in stimulating plant growth by Misra and Bajpai (1983). 


\section{Sprouting percentage $(\%)$}

Sprouting percentage was different for varieties. Candyman recorded significantly maximum sprouting percentage $(87.50 \%)$ followed by Her Majesty $(85.00 \%)$ and American Beauty $(82.50 \%)$. Corms treated treatment $30 \mathrm{~Gy}$ recorded maximum sprouting percentage $(92.36 \%)$ which was at par with 15 Gy (89.58\%), 30 Gy (85.41\%) and 45 Gy $(83.33 \%)$ gamma radiation doses. The finding are in line with the observation of Tiwari et al., (2010), Singh et al., (2013) and Sisodia et al., (2015) who reported lower percentage of sprouting was recorded in all the varieties at higher radiation doses during vM1 generation. This early sprouting of gladiolus corms at lower dose of gamma rays was probably related with the increase in the activities of gibberellins and auxins and disappearance of inhibitors. Misra and Bajpai (1983), Awad and Elbahr (1986), Pranom et al., (1986) and Karki et al., (2010)

\section{Survival percentage $(\%)$}

Minimum survival $(74.30 \%)$ was recorded with treatment 60 Gy. American Beauty recorded significantly maximum survival percentage $(87.50 \%)$ while minimum survival percentage was observed in cv. Her Majesty (75.41\%). Survival percentage was found to be significantly maximum at control $(96.52 \%)$ fallowed by 45 Gy (82.63\%), 15 Gy (79.86\%) and $30 \mathrm{~Gy}(76.38 \%)$. The lowest percentage of survival was recorded at treatment 60 Gy (71.52\%) gamma rays. The gamma radiations proved harmful for survival of gladiolus corms after sprouting. In general the doses increased, progressive decreasing was observed for percentage of survival. Similar results were also reported by Dilta (2003), Singh et al., (2009), and Mahure et al., (2010) who reported ionization resulting in gladiolus affected plant chromosome structure and cell division, which suppress growth or create lethal effect on the cells of the plant and consequently lead to delay and poor percentage of sprouting and low survival of the plant.

\section{Number of sprouts per corm}

Among the variety American Beauty recorded significantly maximum number of sprouts per corm (3.20) while minimum sprouts were recorded in variety Her Majesty (1.73). The effect of radiation and interaction on number of sprouts was found to be non significant. Similar results were observed by Sisodia and Singh (2015) in gladiolus variety Tiger Flame which registered more sprouts due to variation in radio sensitivity of different varieties and gamma doses. The variation among the cultivars regarding number of sprouts may be attributed the effects of mutagens on the merismetic tissues. The decrease in sprouting at higher doses of the mutagens may also be attributed to disturbances at cellular level including chromosomal damages or due to the combined effect of both.

\section{Plant height (cm)}

Variety Candyman recorded significantly maximum plant height at 25, 50 and 75 DAS. Untreated corms (control) recorded maximum plant height at 25 and 50 DAS $(38.04 \mathrm{~cm}$ and $50.78 \mathrm{~cm}$, respectively) whereas, application of 15 Gy resulted in maximum plant height $(82.27 \mathrm{~cm})$ at 75 DAS while, minimum plant height was recorded with 60 Gy treatment. These results are in confirmatory with the finding of Benarji et al., (2002) and Shangwen et al., (2007) who reported lower dose of gamma rays significantly increased plant height, whereas higher doses resulted in reduction of plant height. Reduction in plant height with higher doses of gamma irradiation may be attributed to inactivation of auxin or decreased in auxin content with increase in radiation dose (Dilta et al., 2003). 
Table.1 Mean effect of varieties and gamma radiation on morphological characters of gladiolus in vM1 generation

\begin{tabular}{|c|c|c|c|c|c|c|c|c|c|c|c|c|c|c|c|}
\hline \multirow[t]{2}{*}{ Varieties } & \multirow{2}{*}{ Sprouting (\%) } & \multirow{2}{*}{ Survival (\%) } & \multirow{2}{*}{$\begin{array}{l}\text { Days } \\
\text { taken for } \\
\text { sprouting }\end{array}$} & \multirow{2}{*}{$\begin{array}{l}\text { Number of } \\
\text { sprout } \\
\text { corms }^{-1}\end{array}$} & \multicolumn{3}{|c|}{ Plant height } & \multicolumn{3}{|c|}{ Number of leaves } & \multicolumn{3}{|c|}{ Length of leaves } & \multirow{2}{*}{$\begin{array}{l}\text { Percentage } \\
\text { Leaf } \\
\text { abnormalities }\end{array}$} & \multirow{2}{*}{$\begin{array}{l}\text { Percentage of } \\
\text { morphologically } \\
\text { abnormal plant }\end{array}$} \\
\hline & & & & & $\begin{array}{c}25 \\
\text { DAS }\end{array}$ & $\begin{array}{c}\mathbf{5 0} \\
\text { DAS }\end{array}$ & $\begin{array}{c}75 \\
\text { DAS }\end{array}$ & $\begin{array}{c}25 \\
\text { DAS }\end{array}$ & $\begin{array}{c}\mathbf{5 0} \\
\text { DAS }\end{array}$ & $\begin{array}{c}75 \\
\text { DAS }\end{array}$ & $\begin{array}{c}25 \\
\text { DAS }\end{array}$ & $\begin{array}{c}\text { 50 } \\
\text { DAS }\end{array}$ & $\begin{array}{c}75 \\
\text { DAS }\end{array}$ & & \\
\hline$V_{1}$ & $87.50(69.67)$ & $81.25(66.06)$ & 7.67 & 1.93 & 38.61 & 52.45 & 80.67 & 3.09 & 7.83 & 9.52 & 27.36 & 42.03 & 45.38 & $6.25(2.20)$ & $15.53(3.67)$ \\
\hline$V_{2}$ & $82.50(77.67)$ & $87.50(71.32)$ & 6.73 & 3.20 & 35.25 & 43.57 & 65.64 & 3.31 & 7.03 & 8.23 & 25.55 & 36.81 & 39.99 & $6.32(2.39)$ & $14.52(3.52)$ \\
\hline $\mathbf{V}_{3}$ & $85.00(63.61)$ & $75.41(62.33)$ & 7.80 & 1.73 & 34.57 & 45.75 & 73.80 & 3.32 & 6.80 & 7.69 & 26.80 & 37.51 & 41.56 & $8.06(2.67)$ & $13.52(3.41)$ \\
\hline S.E m \pm & 2.43 & 2.62 & 0.31 & 0.12 & 1.00 & 1.31 & 2.54 & 0.15 & 0.19 & 0.18 & 0.54 & 0.93 & 0.92 & 0.11 & 0.17 \\
\hline CD at $5 \%$ & 7.06 & 5.40 & 0.64 & 0.34 & 2.90 & 3.81 & 7.40 & NS & 0.44 & 0.52 & NS & 2.31 & 2.67 & 0.32 & NS \\
\hline \multicolumn{16}{|c|}{ Radiation doses } \\
\hline $\mathbf{I}_{\mathbf{0}}$ & $85.41(82.32)$ & $96.52(82.87)$ & 7.44 & 2.18 & 38.04 & 50.78 & 80.56 & 3.02 & 7.24 & 8.91 & 29.53 & 42.98 & 46.81 & $0.00(0.70)$ & $0.00(0.70)$ \\
\hline $\mathbf{I}_{1}$ & $89.58(68.09)$ & $79.86(64.19)$ & 7.22 & 2.33 & 38.40 & 50.64 & 82.27 & 3.27 & 7.33 & 9.16 & 26.78 & 40.02 & 43.30 & $3.08(1.86)$ & $14.68(3.81)$ \\
\hline $\mathbf{I}_{2}$ & $92.36(64.85)$ & $76.38(61.52)$ & 7.33 & 2.33 & 36.80 & 47.80 & 76.80 & 3.22 & 7.29 & 8.91 & 27.09 & 39.04 & 43.44 & $6.27(2.62)$ & $17.86(4.22)$ \\
\hline $\mathbf{I}_{3}$ & $83.33(71.04)$ & $82.63(66.10)$ & 7.11 & 2.51 & 35.76 & 45.91 & 69.13 & 3.49 & 7.36 & 8.29 & 25.36 & 36.44 & 39.41 & $8.14(2.88)$ & $19.34(4.34)$ \\
\hline $\mathbf{I}_{4}$ & $65.27(74.30)$ & $71.52(58.17)$ & 7.89 & 2.09 & 31.73 & 41.16 & 58.09 & 3.20 & 6.87 & 7.13 & 24.11 & 35.42 & 38.61 & $16.90(4.03)$ & $20.74(4.51)$ \\
\hline S.E $\mathbf{~ m \pm}$ & 3.13 & 3.39 & 0.4 & 0.15 & 1.29 & 1.69 & 3.28 & 0.20 & 0.34 & 0.23 & 0.70 & 1.20 & 1.19 & 0.14 & 0.23 \\
\hline CD at $5 \%$ & 9.12 & 6.97 & NS & NS & 3.74 & 4.92 & 9.55 & NS & NS & 0.67 & 2.05 & 3.50 & 3.45 & 0.42 & 0.67 \\
\hline \multicolumn{16}{|c|}{ Interaction } \\
\hline $\mathbf{V}_{1} \mathbf{I}_{0}$ & $95.83(80.35)$ & $95.83(80.35)$ & 7.67 & 1.73 & 42.33 & 59.73 & 94.33 & 3.07 & 8.27 & 10.60 & 30.60 & 47.00 & 49.83 & $0.00(0.70)$ & $0.00(0.70)$ \\
\hline $\mathbf{V}_{1} \mathbf{I}_{1}$ & $77.08(61.77)$ & $61.77(77.08)$ & 7.33 & 2.00 & 41.27 & 55.87 & 91.00 & 3.07 & 7.67 & 10.67 & 27.00 & 44.80 & 49.26 & $1.98(1.56)$ & $16.09(4.04)$ \\
\hline $\mathbf{V}_{1} \mathbf{I}_{2}$ & $83.33(70.51)$ & $75.00(60.51)$ & 8.00 & 1.87 & 37.67 & 51.07 & 82.93 & 3.20 & 7.80 & 10.13 & 28.53 & 39.20 & 43.33 & $5.23(2.38)$ & $19.95(4.47)$ \\
\hline $\mathbf{V}_{1} \mathbf{I}_{3}$ & $87.50(69.72)$ & $87.50(69.72)$ & 7.00 & 2.07 & 37.40 & 49.73 & 70.67 & 3.27 & 7.93 & 8.33 & 25.60 & 38.87 & 41.80 & $5.93(2.48)$ & $18.92(4.38)$ \\
\hline $\mathbf{V}_{1} \mathbf{I}_{4}$ & $83.33(65.99)$ & $70.83(57.93)$ & 8.33 & 2.00 & 34.40 & 45.87 & 64.40 & 2.87 & 7.47 & 7.87 & 25.07 & 40.27 & 42.70 & $14.57(3.68)$ & $22.69(4.78)$ \\
\hline $\mathbf{V}_{2} \mathbf{I}_{0}$ & $97.92(85.17)$ & $97.92(85.17)$ & 6.33 & 2.73 & 38.20 & 48.07 & 71.53 & 3.20 & 7.27 & 8.27 & 28.00 & 39.60 & 42.63 & $0.00(0.70)$ & $0.00(0.70)$ \\
\hline $\mathbf{V}_{2} \mathbf{I}_{1}$ & $97.92(85.17)$ & $91.67(73.45)$ & 7.00 & 3.40 & 36.87 & 48.00 & 73.33 & 3.27 & 6.93 & 8.53 & 26.53 & 37.87 & 41.50 & $2.91(1.84)$ & $16.80(4.03)$ \\
\hline $\mathbf{V}_{2} \mathbf{I}_{2}$ & $83.33(66.62)$ & $83.33(66.62)$ & 6.67 & 3.47 & 36.00 & 42.93 & 64.73 & 3.07 & 7.00 & 8.60 & 24.93 & 38.67 & 41.73 & $7.46(2.80)$ & $15.12(3.94)$ \\
\hline $\mathbf{V}_{2} \mathbf{I}_{3}$ & $95.83(83.10)$ & $85.42(68.27)$ & 6.33 & 3.67 & 34.20 & 41.00 & 62.80 & 3.47 & 7.07 & 8.53 & 24.33 & 35.20 & 38.70 & $5.78(2.49)$ & $16.92(4.16)$ \\
\hline $\mathbf{V}_{2} \mathbf{I}_{4}$ & $85.42(68.27)$ & $79.17(63.10)$ & 7.33 & 2.73 & 31.00 & 37.87 & 55.80 & 3.53 & 6.87 & 7.20 & 24.00 & 32.73 & 35.40 & $16.88(4.12)$ & $22.90(4.76)$ \\
\hline $\mathbf{V}_{3} \mathbf{I}_{0}$ & $93.75(81.45)$ & $95.83(83.10)$ & 8.33 & 2.07 & 33.60 & 44.53 & 75.80 & 2.80 & 6.20 & 7.87 & 30.00 & 42.33 & 47.96 & $0.00(0.70)$ & $0.00(0.70)$ \\
\hline $\mathbf{V}_{\mathbf{3}} \mathbf{I}_{\mathbf{1}}$ & $70.83(57.34)$ & $70.83(57.34)$ & 7.33 & 1.60 & 37.07 & 48.07 & 82.47 & 3.47 & 7.40 & 8.27 & 26.80 & 37.40 & 39.13 & $4.37(2.18)$ & $11.15(3.36)$ \\
\hline $\mathbf{V}_{3} \mathbf{I}_{2}$ & $70.83(57.41)$ & $70.83(57.41)$ & 7.33 & 1.67 & 36.73 & 49.40 & 82.73 & 3.40 & 7.07 & 8.00 & 27.80 & 39.27 & 45.26 & $6.80(2.68)$ & $18.53(4.25)$ \\
\hline $\mathbf{V}_{\mathbf{3}} \mathbf{I}_{\mathbf{3}}$ & $75.00(60.31)$ & $75.00(60.31)$ & 8.00 & 1.80 & 35.67 & 47.00 & 73.93 & 3.73 & 7.07 & 8.00 & 26.13 & 35.27 & 37.73 & $13.43(3.68)$ & $22.13(4.74)$ \\
\hline $\mathbf{V}_{\mathbf{3}} \mathbf{I}_{\mathbf{4}}$ & $77.08(61.56)$ & $64.58(53.50)$ & 8.00 & 1.53 & 29.80 & 39.73 & 54.07 & 3.20 & 6.27 & 6.33 & 23.27 & 33.27 & 37.73 & $16.61(4.10)$ & $15.76(4.00)$ \\
\hline S.E $\mathbf{m} \pm$ & 5.42 & 3.39 & 0.69 & 0.26 & 2.23 & 2.93 & 5.68 & 0.34 & 0.34 & 0.40 & 1.22 & 2.08 & 2.06 & 0.24 & 0.39 \\
\hline CD at $5 \%$ & NS & NS & NS & NS & NS & NS & NS & NS & NS & NS & NS & NS & NS & NS & NS \\
\hline C.V. $(\%)$ & 13.36 & 10.79 & 11.49 & 19.71 & 10.67 & 10.73 & 13.40 & 12.8 & 8.02 & 8.13 & 7.93 & 9.29 & 8.44 & 17.95 & 19.81 \\
\hline
\end{tabular}

*Figures in parentheses are arc sine transformed value 
Higher doses mutagen proved to be injurious as promote physiological disturbance, retarded cell division by arresting the mitotic division and had ill-effect on auxin (Patil et al., 2010, Kole et al., 2005 and Singh et al., 2013).

\section{Number of leaves plant $^{-1}$}

In case of varieties, Candyman was found to have maximum number of leaves per plant at 50 and 75 DAS (7.83 and 9.52, respectively). Application of 15 Gy recorded maximum number of leaves (9.16) while, minimum number of leaves was recorded at $60 \mathrm{~Gy}$ treatment (7.13). The reduction in number of leaves may be due to changes in auxin level or due to inactivation of auxins was hypothesized by Datta and Datta (1953). Inhibition of mitotic activities and chromosome damage associated with secondary physiological damage could also be the cause for reduction in vegetative growth as reported by Sparrow (1961) who studied the cytological effects of ionization of different plants.

\section{Length of leaves (cm)}

Variety Candyman have maximum length of leaf at 25, 50 and 75 DAS whereas minimum length was recorded in variety American Beauty. In case of gamma radiation treatments, control was recorded significantly maximum leaves length at 25, 50 and 75 DAS while minimum leaf length was recorded at 60 Gy treatments. The reduction in leaf length due to gamma ray and $\mathrm{X}$ - ray irradiation was associated with abnormalities which are resulting from disturbances by phytochromes (Moh, 1962). Sparrow (1961), while working on cytological effect of radiation, concluded that the decrease in vegetative growth is a result of radiation induced cytological changes such as chromosomal damages, inhibited mitotic division, degeneration of nuclei, cell enlargement, etc.

\section{Leaves abnormalities (\%)}

The percentage of leaf abnormalities were significantly increased in cv. Her Majesty $(8.06 \%)$. The percentage of leaf abnormalities were increased by increasing of gamma radiation doses with maximum being reported at $60 \mathrm{~Gy}(16.90 \%)$. Leaf abnormalities were not observed at control. Similar results have been observed by Kapadiya et al., (2016) in Chrysanthemum, who reported vegetative abnormalities increased significantly due to effect of higher mutagenic levels.

\section{Morphologically abnormal plant (\%)}

The percentage of morphologically abnormal plants was not significantly influenced by gladiolus varieties. Significantly maximum percentage of morphological abnormal plants was recorded at $60 \mathrm{~Gy}(20.74 \%)$ while, no abnormal plant was recorded at control. Similar results were obtained by Tiwari et al., (2010) and Singh et al., (2013) who reported that morphological abnormalities in foliage and florets were increased in the irradiated corms with increase to gamma rays. Similar results after gamma irradiation while working with Dahlia cv. Pinki were also reported by (Dwivedi and Banerji, 2008). The variation might be caused due to chromosomal aberration, disturbances in the production and/or distribution of growth substances caused by the mutagens (Gunckel, 1957).

\section{References}

Awad, A.R.E. and Elbahr, K. 1986. Growth regulators and gamma irradiation treatments affecting the sprouting and endogenous hormones in gladiolus. Acta-Horticulturae, 177(2): 612.

Banerji, B.K. and Datta, S.K., 2002. Induction and analysis of gamma ray-induced flower head shape mutation in 'Lalima' chrysanthemum

(Chrysanthemum 
morifolium). Indian Journal of Agricultural Sciences, 72(1): 6-10.

Datta, P.K. and Datta, C. (1953). High dosage of X-irradiation on inhibition of growth in rice seedlings. Science and Culture, 18,500 - 502

Dilta, B.S., Sharma, Y.D., Gupta, Y.C., Bhalla, R. and Sharma, B.P., 2003. Effect of gamma-rays on vegetative and flowering parameters of chrysanthemum. Journal of Ornamental Horticulture, 6(4): 328-334.

Dwivedi, A.K, and Banerji, B.K. 2008. Effects of gamma irradiation on Dahlia cv. 'Pinki' with particular reference to induction of somatic mutation. Journal of Ornamental Horticulture, 11(2): 148151.

Gunckel, J.E., 1957. The effects of ionizing radiation on plants. Morphological effects. Quantitative Review of Biology, 32: 46-56.

Kapadiya, D. B. Chawla, S. L. Patel, A. I. and Bhatt, D. 2016. Induction of variability through in vivo mutagenesis in chrysanthemum (Chrysanthemum morifolium Ramat.) var. Jaya. Indian Journal of Horticulture, 73(1): 141-144.

Karkri, K. and Srivastva, R. 2010. Effect of gamma irradiation in gladiolus (Gladiolus grandiflorus L.). Pantnagar Journal of Research. 8(1): 55-63.

Kole, P. C. and Meher, S. K. 2005. Effect of gamma rays of some quantitative and qualitative characters in zinnia (Ginnia elegance) N.J. Jacguin in M1 generation. Journal of Ornamental Horticulture, 8(4):303-305.

Mahure, H.R., Choudhary, M.L., Prasad, K.V. and Singh, S.K. 2010. Mutation in chrysanthemum through gamma irradiation. Indian Journal of Horticulture, 67: 356-58.

Misra, R.L. and Bajpai, P.N. 1983. Effects of mutagens on shooting, leaf number, heading, plant height and spike length in gladioli. Indian Journal of Horticulture, 40: 107-111.

Moh, C.C. (1962). The use of radiation induced mutations in crop breeding in Latin America and some biological effects of radiation in Coffee. International Journal of Applied Radiation Isotopes, 13, 467 - 475.

Patil, D. S., Patil, H.E. and Dhaduk, B.K., 2010a. Response of gamma radiation on vegetative and floral characters of commercial varieties of gladiolus (Gladiolusgrandiflorus L.). Abst: National Symposium on Life Style Floriculture: Challenges and Opportunities, YSPU H\&F, Nauni, Solan (H.P.). Pp. 21.

Panse, V. J. and Sukhatme, P. V. 1967. Statistical methods for Agricultural Workers, Published by I. C. A. R., New Delhi.

Patil S and Dhaduk B. K. 2009. Effect of gamma radiation on vegetative and floral characters of commercial varieties of gladiolus (Gladiolus hybrid L.). Journal of Ornamental Horticulture, 12(4): 232-238.

Pranom, P., Sangtham, K. and Orwan, M., 1986. Production of gladiolus: Effect of gamma irradiation on certain characteristics of gladiolus var. Spic and Span, Norwich Canary. Research and Development Institute. Research Reports. Kasestsart University (Thailand), 85.

Shangwen, H. and Xian, Z. 2007. 60Co- $\gamma$ Irradiation gladiolus main quality indices biological characters. Chinese Agricultural Science Bulletin, 4: 112 115.

Singh, A.K. 2006. Flower crops: cultivation and management. New India Publishing Agency, Pitam pura, New Delhi. P. 147.

Singh, V.S., Banerji, B.K., Dwivedi, A.K. and Verma, A.K. 2009. Effect of gamma irradiation on African marigold 
(Tagetes erecta L.) cv.Pusa Narangi Gainda. J. Hortl. Sci. 4(1):36-40

Singh, A.K. and Kumar, A. 2013. Studies of gamma irradiation on morphological characters in gladiolus. Asian Journal of Horticulture, 8: 299-303.

Sisodia A. and Singh A. K. 2015. Studies on gamma ray induced mutants in gladiolus. Indian Journal of Agricultural Sciences. 85(1): 79-86.

Sparrow, A.H. (1961). Types of ionizing radiations and their cytogenetic effects.
Mutation Plant Breeding NAS-NRC, $891,55-119$.

Srivastava, P. Singh, R. P. and Tripathi, V. R. 2007. Response of gamma radiation on vegetative and floral characters of gladiolus. Asian Journal of Horticulture, 10 (2): 135-136.

Tiwari, A.K., Srivastava, R.M., Kumar, V., Yadav. L.B. and Misra, S.K. 2010. Gamma rays induced morphological changes in gladiolus. Progressive Agriculture, 10: 75 - 82.

\section{How to cite this article:}

Abhilash Shukla, Gaurav Sharma, Sushil Kashyap and Manisha Netam. 2018. Induced Mutagenesis for Morphological Changes in Gladiolus (Gladiolus grandiflorus L.). Int.J.Curr.Microbiol.App.Sci. 7(11): 2493-2499. doi: https://doi.org/10.20546/ijcmas.2018.711.283 